\title{
ANALISIS PENGARUH ORIENTASI BELANJA DAN KEPERCAYAAN KONSUMEN TERHADAP MINAT BELI
}

\author{
Sabda Dian Nurani Siahaan'), Haryani Pratiwi Sitompul ${ }^{2)}$ \\ Fakultas Ekonomi, Universitas Negeri Medan \\ sabda@unimed.ac.id ${ }^{1)}$, tiwisitompul@,unimed.ac.id ${ }^{2)}$
}

\begin{abstract}
The development of Information, Communication and Technology (ICT) is currently being welcomed by the Indonesian through the growing development of digital businesses. The increasing of digital businesses nowadays must be followed by a business competition strategy, example: online shops. Therefore an analysis of the factors that impact the consumer buying interest in online shopping was needed. Thus this study aims to determine the effect of Shopping Orientation and Consumer Confidence on Consumer Buying Interest. The method used in this research is quantitative research methods. The population in this study were students of the Department of Economics, Faculty of Economics, Universitas Negeri Medan and the sample used was 205 people by using purposive sampling technique. The data collection technique was using a questionnaire and the data analysis method was multiple linear regression analysis. Based on the research results, it is found that (1) Shopping Orientation has a positive and significant effect on Buying Interest, (2) Consumer Trust has a positive and significant effect on Buying Interest and (3) Shopping Orientation and Consumer Trust simultaneously have a positive and significant effect on Buying Interest.
\end{abstract}

Keywords: Shopping Orientation, Consumer Confidence, Buying Interest

\section{PENDAhuluan}

Perkembangan teknologi, informasi, dan komunikasi (TIK) / Information, Communication, and Technologi (ICT) telah memberikan dampak yang besar dalam kehidupan masyarakat di Indonesia. Segala sesuatunya menjadi lebih mudah dan praktis dengan adanya teknologi, informasi dan komunikasi tersebut. Perkembangan teknologi dapat dirasakan dalam berbagai bidang mulai dari transportasi, komunikasi elektronik (Nusarika \& Purnami, 2015). Hal yang menggembirakan adalah bahwa perkembangan teknologi tersebut disambut baik oleh masyarakat Indonesia dan bukan malah menutup diri dengan adanya perkembangan tersebut. Masyarakat Indonesia merespon dengan baik perkembangan teknologi untuk berkomunikasi, sosial, dan bahkan untuk aktivitas dalam bisnis. Berdasarkan data platform media We Are Social (2020) menunjukkan bahwa pengguna internet di Indonesia adalah sebanyak 175,4 juta orang, sementara jumlah penduduk di Indonesia adalah sebanyak 272,1 juta orang. Data tersebut menunjukkan bahwa setengah dari penduduk Indonesia adalah pengguna internet. Pengguna internet tersebut adalah masyarakat yang berada pada rentang usia 16-64 tahun, dimana orang-orang pada usia tersebut adalah para remaja, anak sekolah, kuliah, karyawan, dan orang tua. Para pengguna internet tersebut menghabiskan waktu menjelajahi dunia maya sekitar 7 jam 59 menit. Angka tersebut sangatlah tinggi sehingga menjadikan Indonesia berada dalam 10 besar negara di dunia yang paling aktif menggunakan internet (GoodNews, 2020).

Ketertarikan masyarakat Indonesia dalam bermedia sosial dan menggunakan internet tersebut tentu saja sangat disayangkan jika tidak dimanfaatkan ke arah yang positif. Dengan kata lain, keadaan ini dapat dijadikan menjadi peluang bisnis oleh pengusaha-pengusaha yang ada di Indonesia. Tidak sedikit masyarakat Indonesia mulai dari kalangan masyarakat biasa hingga pengusaha membuka bisnis online. Bisnis online sedang marak dan dimanfaatkan oleh siapapun. Hal tersebut dibuktikan dengan semakin menjamurnya bisnis-bisnis di Indonesia berbasis digital seperti Tokopedia, Lazada, Bukalapak, Shopee, dll. Online Shop seperti Tokopedia dan Lazada juga berhasil menjadi salah satu perusahaan Unicorn di Indonesia. Begitu menjanjikannya usaha berbasis digital ini sehingga terbukti telah menjadi perusahaan start up Unicorn. Kalangan masyarakat biasa 
juga telah melihat peluang ini sehingga banyak yang mencoba untuk berjualan online. Berjualan melalui internet dipandang memiliki kemudahan dibandingkan dengan berjualan secara langsung karena tentu saja berjualan online tidak membutuhkan biaya pembangunan toko, gaji karyawan, dan biaya tetap lainnya.

Masyarakat Indonesia dewasa ini juga cenderung untuk bertransaksi, berbelanja secara online karena dianggap lebih mudah, efektif, dan efisien. Tidak perlu berbelanja keluar rumah, mengeluarkan biaya/ongkos, cukup memesan barang secara online saja maka barang yang kita pesan akan tiba di tempat. Diantara banyaknya online shop, salah satu yang sedang diminati oleh masyarakat saat ini adalah Shopee. Shopee merupakan toko online yang menyediakan jasa jual beli barang melalui sebuah aplikasi yang dapat diunduh oleh pengguna melalui Plays Store. Shopee menyediakan berbagai macam produk mulai dari pakaian, tas, sepatu, aksesoris, kosmetik, peralatan dapur, juga HP/Laptop, dll. Barang-barang yang ditawarkan adalah barang-barang kebutuhan seharihari sehingga online shop sejenis ini sangat sering dikunjungi oleh masyarakat. Saat ini Shopee juga sedang gencar melakukan berbagai macam promosi seperti diskon untuk barang-barang tertentu, dan diskon besar-besaran pada saat tertentu. Hal tersebut adalah sebagai upaya untuk menarik minat beli konsumen dan untuk mempertahankan konsumen. Minat beli merupakan sebuah keinginan untuk memiliki suatu produk tertentu yang muncul karena kebutuhan. Minat beli muncul karena beberapa faktor, salah satunya adalah orientasi belanja. (Sreya \& Raveendran, 2016) menjelaskan bahwa orientasi belanja pembeli mengacu pada perhatian pembeli pada merek, nilai, resiko yang muncul dalam kegiatan berbelanja. Proses pembelian suatu produk secara umum akan dipengaruhi oleh orientasi belanja. Orientasi belanja tersebut terlihat dari pencarian informasi tentang produk tersebut, mengevaluasi, lalu memilih.

Saat ini, penjualan barang online (online shop) memiliki kelemahan, khususnya dalam hal jual beli di website, misalnya barang yang ditawarkan di toko online tidak sesuai dengan yang diharapkan oleh pelanggan. Sering sekali barang yang dipajang di toko online berbeda dengan yang sebenarnya. Selain itu, para pedagang di toko online kadang-kadang menjual barang palsu dengan brand terkenal, yang mengakibatkan konsumen tertipu dan rugi atas pembelian barang tersebut. Hal tersebut sangat berisiko mengurangi kepercayaan konsumen. Hal ini jugalah yang menjadi permasalahan lainnya dalam penjualan online di Indonesia yaitu membangun kepercayaan konsumen. Namun tidak bisa dipungkiri juga, tidak semua barang-barang di toko online bersifat menipu, banyak juga penjual yang jujur dan memberikan pelayanan yang terbaik bagi konsumen sehingga tidak merusak citra perusahaan dan juga kepercayaan konsumen. (Lapian \& Roring, 2018) mengatakan jika kepercayaan konsumen terhadap suatu produk semakin tinggi, maka kesetiaan konsumen terhadap produk tersebut akan semakin tinggi. Selanjutnya (Haekal \& Widjajanta, 2016) menjelaskan bahwa membangun dan menjalin sebuah rasa kepercayaan antara perusahaan dan pelanggan untuk jangka panjang adalah faktor yang penting untuk menciptakan rasa aman, rasa saling percaya, dan loyalitas.

Melihat sedang maraknya berbelanja online di kalangan masyarakat, maka penulis tertarik mengadakan penelitian untuk mengetahui faktor apa yang mempengaruhi motif berbelanja konsumen pada online shop Shopee. Online shop Shopee dipilih sebagai objek karena online shop ini sedang trendy dan digemari oleh masyarakat. Orientasi Belanja dan dan Kepercayaan Konsumen adalah variabel bebas dalam penelitian ini, sementara variabel terikat adalah Minat Beli konsumen. Adapun yang menjadi responden dalam penelitian ini adalah mahasiswa jurusan Ekonomi, Universitas Negeri Medan yang sudah pernah berbelanja pada Shopee Online Shop. Pemilihan mahasiswa menjadi responden adalah karena berdasarkan pengamatan peneliti, konsumen yang paling banyak melakukan pembelian secara online adalah mahasiswa. Menurut para mahasiswa, berbelanja online merupakan pilihan yang tepat daripada harus berbelanjan secara offline, lebih mudah, efektif dan hemat. Dengan adanya penelitian ini, diharapkan dapat menjadi referensi bagi setiap pedagang online agar bisa meningkatkan produktivitas kegiatan bisnisnya, mengetahui pentingnya memahami orientasi belanja dan membangun kepercayaan konsumen.

\section{KAJIAN LITERATUR}

\subsection{Orientasi Belanja}


Dalam berbelanja baik secara online maupun offline, seorang konsumen didorong oleh suatu motif/keinginan untuk berbelanja yang disebut dengan orientasi belanja (Shopping Orientation). (Kusuma \& Septarini, 2013) mendefenisikan bahwa orientasi belanja merupakan bagian dari gaya hidup individu dengan menekankan pada kegiatan perilaku konsumen yang sebenarnya. (Imari et al., 2017) menyatakan orientasi belanja sebagai gaya pembelanja yang menempatkan penekanan khusus pada spesifik perbelanjaan yang meliputi kegiatan belanja, ketertarikan dan pendapat, serta merefleksikan pandangan perbelanjaan sebagai kompleks sosial, rekreasi dan fenomena ekonomi. Berdasarkan pengertian di atas dapat disimpulkan bahwa orientasi belanja merupakan kecenderungan berbelanja seorang individu yang dipengaruhi oleh prinsip atau perilaku individu tersebut. Orientasi berbelanja setiap konsumen pasti berbeda satu sama lain. Orientasi berbelanja seorang konsumen mencerminkan pandangan konsumen secara sosial, ekonomi, budaya dan juga tujuan pribadi dalam berbelanja, karena itu dipercaya bahwa orientasi berbelanja konsumen juga dapat merefleksikan keadaan dan nilai ekonomi, sosial, budaya, serta lingkungan konsumen itu sendiri (Ikranegara, 2017).

(Gita Ardy Putri, 2020) menyatakan terdapat 7 dimensi orientasi berbelanja yaitu : 1) Shopping Enjoyment, merupakan kesenangan individu ketika dalam melakukan berbelanja, 2) Brand/Fashion Consciousness, merupakan kesadaran individu terhadap merek atau mode busana, 3) Price Consciousness, merupakan individu terhadap harga produk, 4) Shopping Confidence, merupakan kepercayaan individu menyatakan intensi pembeli, 5) Convinience/Time Consciousness, merupakan kesadaran individu terhadap waktu dan kenyamanan ketika berbelanja, 6) In-home Tendency, merupakan kecenderungan umum yang ditunjukan oleh individu untuk melakukan pembelian melalui rumah, 7) Brand/Store Loyalty yang merupakan kesetiaan individu terhadap merek dan toko ketika melakukan kegiatan berbelanja.

Berdasarkan hasil penelitian sebelumnya, (Nusarika \& Purnami, 2015) mengatakan bahawa orientasi belanja berpengaruh positif dan signifikan terhadap minat beli konsumen. Selanjutnya (Wijayanti et al., 2018) juga menemukan hal yang sama yaitu orientasi belanja berpengaruh positif terhadap minat beli konsumen, dimana orientasi belanja konsumen dipengaruhi oleh harga dan motivasi.

\subsection{Kepercayaan Konsumen}

Kepercayaan Konsumen adalah persepsi dari sudut pandang konsumen akan keandalan penjual dalam pengalaman dan terpenuhinya harapan dan kepuasan konsumen (Firdayanti, 2013). Kepercayaan merupakan suatu pondasi dalam sebuah proses bisnis (Anwar \& Adidarma, 2016). Dalam transaksi jual beli tentu saja ada usur kepercayaan, terutama dari pihak konsumen. Jika seseorang bersedia membeli suatu produk, maka hal tersebut tentu saja karena adanya unsur kepercayaan konsumen terhadap produk yang dibelinya. Bertransaksi secara online memiliki resiko yang lebih tinggi dibandingkan dengan bertransaksi secara offline. Jika bertransaksi secara offline, barang yang ingin dibeli dapat dilihat pembayaran juga dilakukan secara langsung sehingga tida menimbulkan kekhawatiran begi penjual dan pembeli. Bertransaksi secara online, selain karena lebih efektif dan efisien, memiliki resiko yang lebih tinggi karena memungkinkan terjadinya penipuan uang dan produk. Produk yang dilihat secara online bisa jadi berbeda dengan yang sebenarnya dan kualitasnya tidak bisa dijamin. Oleh karena itu, untuk menghindari juga adannya penipuan, maka diberlakukan sistem pembayaran Cash On Delivery (COD), supaya transaksi yang dilakukan oleh si pembeli terjamin.

(Firdayanti, 2013) dalam penlitiannya mengenai persepsi risiko melakukan e-commerce dengan kepercayaan konsumen dalam membeli produk fashion online, menyatakan bahwa tingkat kepercayaan konsumen dalam membeli produk fashion melalui Facebook pada mahasiswa mahasiswa UNNES jurusan psikologi tergolong rendah. Penelitian tersebut juga mengatakan bahwa terdapat hubungan antara persepsi terhadap resiko melakukan pembelian online. Mahasiswa yang memiliki persepsi terhadap risiko yang tinggi pada umumnya memiliki kepercayaan konsumen yang rendah begitu pula sebaliknya mahasiswa yang memiliki persepsi terhadap risiko yang rendah memiliki kepercayaan konsumen yang tinggi (Firdayanti, 2013). Hal tersebut menunjukkan bahwa tingkat kepercayaan online ditentukan oleh persepsi. Persepsi tersebut terbentuk dari tingkat pelayanan yang diberikan oleh online shop itu sendiri. Menurut (Afnina \& Hastuti, 2018) 
kepercayaan pembeli terhadap situs jual beli online terletak pada popularitas situs tersebut, semakin popular situs tersebut pembeli akan merasa lebih yakin untuk berbelanja disana. Jika online memberikan pelayanan yang baik, produk-produk yang dipajang secara online adalah real (gambar sesuai dengan aslinya), sistem transaksi yang aman, maka persepsi konsumen yang timbul adalah bahwa berbelanja online memiliki resiko yang rendah sehingga kepercayaan konsumen dalam berbelanja online pun meningkat. Semakin tinggi tingkat kepercayaan konsumen terhadap suatu situs belanja online maka akan semakin tinggi pula minat belanja konsumen melalui situs tersebut (Anwar \& Adidarma, 2016). Penelitian tersebut juga menemukan terdapat pengaruh yang positif kepercayaan online dan minat beli.

Jika konsumen mendapatkan pengalaman yang baik dalam bertransaksi secara online dan merasa yakin tentang transaksi online ataupun belanja di toko online, mereka lebih cenderung memiliki niat membeli lebih tinggi pada situs toko online (Suhari, 2011). Lebih lanjut lagi (Suhari, 2011) menemukan terdapat pengaruh yang positif kepercayaan online dan minat beli. Sehingga berdasarkan penemuan terdahulu tersebut, maka hipotesis dalam penelitian ini adalah terdapat pengaruh positif dan signifikan antara kepercayaan dan minat beli konsumen.

\subsection{Minat Beli}

Minat beli konsumen merupakan salah satu bagian dari sikap konsumen dalam mengkonsumsi suatu barang. Minat yang muncul dalam melakukan pembelian menciptakan suatu motivasi berada dalam pikiran seseorang dan menjadi suatu kegiatan yang sangat kuat yang pada akhirnya ketika seorang konsumen harus memenuhi kebutuhannya akan mengaktualisasikan apa yang ada didalam pikiran tersebut (Khotimah \& Febriansyah, 2018). Minat beli adalah suatu sikap dari konsumen untuk bertindak sebelum melakukan pembelian terhadap sebuah produk (Nurrahmanto, 2015). Selanjutnya (Nurrahmanto, 2015) mengatakan minat beli menciptakan suatu motivasi terhadap pikiran konsumen, yang pada akhirnya ketika konsumen harus memenuhi kebutuhannya maka akan mengaktualisasikan apa yang ada di dalam pikirannya.

\section{METODE}

Metode yang digunakan dalam penelitian ini adalah kuantitatif, yaitu data penelitian berupa angka-angka dan analisis menggunakan statistik (Sugiyono, 2012). Variabel dalam penelitian ini adalah Orientasi Belanja $\left(\mathrm{X}_{1}\right)$ dan Kepercayaan Konsumen $\left(\mathrm{X}_{2}\right)$ sebagai variabel bebas (variabel independen) dan Minat Beli (Y) sebagai variabel terikat (variabel dependen).

Populasi yang digunakan dalam penelitian ini adalah mahasiswa Jurusan Ekonomi, Fakultas Ekonomi, Universitas Negeri Medan yang mengetahui, pernah melihat iklan, dan pernah melakukan pembelian di situs jual beli online Shopee. Populasi adalah gabungan seluruh elemen yang memiliki serangkaian karakteristik serupa yang mencakup semesta untuk kepentingan riset pemasaran (Malhotra, 2009). Metode penarikan sampel adalah penentuan sampel dilakukan dengan teknik Purposive Sampling. Purposive Sampling adalah teknik penentuan sampel dengan pertimbangan tertentu (Bibi \& Jati, 2015). Sampel dalam penelitian adalah berjumlah 205 orang.

Teknik pengumpulan data pada penelitian adalah melalui kuisioner yang disebarkan kepada sampel penelitian. Kuisioner dalam penelitian ini terdiri dari 25 butir pernyataan yang menggunakan skala Likert terdiri dari 5 alternatif jawaban yaitu Sangat Setuju $=5$, Setuju $=4$, Netral $=3$, Tidak Setuju $=2$, dan Sangat Tidak Setuju $=1$. Data pada penelitian ini berupa skor yang diperoleh dari hasil pengisian angket/kuisioner oleh sampel penelitian. Variabel Orientasi Belanja $\left(\mathrm{X}_{1}\right)$ terdiri dari 6 (enam) indikator yaitu, Shopping Enjoyment, Brand /Fashion Consciousness, Price Consciousness, Shopping Confidence, Convinience / Time Consciousness, dan In-home Tendency. Variabel Kepercayaan Konsumen $\left(\mathrm{X}_{2}\right)$ terdiri dari 3 (tiga) indikator yaitu Security, Privacy, dan Reliability dan variabel Minat Belanja (Y) juga terdiri dari 3 (tiga) indikator yaitu Ketertarikan, Keinginan, dan Keyakinan.

Metode analisis data yang digunakan dalam penelitian ini adalah Analisis Regresi Linear Berganda, Uji Hipotesis $\mathrm{T}$ dan $\mathrm{F}$, dan perhitungan Koefisien Determinasi dengan menggunakan program SPSS. Analisis regresi berganda bertujuan untuk mengetahui pengaruh antara variabel independen yaitu Orientasi Belanja $\left(\mathrm{X}_{1}\right)$ dan Kepercayaan Konsumen $\left(\mathrm{X}_{2}\right)$ terhadap variabel dependen yaitu Minat Beli Konsumen (Y) yaitu mahasiswa jurusan Ekonomi, Fakultas Ekonomi, 
Universitas Negeri Medan. Untuk mengetahui besarnya pengaruh variabel X terhadap Y digunakan rumus regresi berganda sebagai berikut :

$$
\begin{aligned}
& \mathrm{Y}=\mathrm{bo}+\mathrm{b} 1 \mathrm{X} 1+\mathrm{b} 2 \mathrm{X} 2+\mathrm{b} 3 \mathrm{X} 3+\mathrm{e} \\
& \text { Keterangan : } \\
& \text { Y : Minat Beli } \\
& \text { bo : Konstanta } \\
& \text { b1, b2, : Koefisien Regresi } \\
& \mathrm{X} 1 \quad \text { : Orientasi belanja } \\
& \text { X2 : Kepercayaan Konsumen } \\
& \text { e : error }
\end{aligned}
$$

Uji parsial (Uji-t) dilakukan untuk menguji setiap variabel independen apakah berpengaruh terhadap variabel dependen. Dalam penelitian ini, uji hipotesis ini dilakukan untuk mengetahui pengaruh variabel $\mathrm{X}_{1}$ Orientasi Belanja dan variabel $\mathrm{X}_{2}$ Kepercayaan Konsumen secara terpisah terhadap variabel Y Minat Beli. Uji hipotesis ini dilakukan dengan cara membandingkan $t$ hitung dengan $\mathrm{t}$ tabel. Jika $\mathrm{t}$ hitung $>\mathrm{t}$ tabel maka hipotesis diterima dan sebaliknya. Untuk melihat siginifikansi pengaruh variabel independen terhadap variabel dependen maka nilai signifikansi harus lebih kecil dari $0,05(<0,05)$.

Uji simultan (Uji-F) dilakukan untuk mengetahui pengaruh variabel $\mathrm{X}_{1}$ Orientasi Belanja dan variabel $\mathrm{X}_{2}$ Kepercayaan Konsumen secara simultan terhadap variabel $\mathrm{Y}$ Minat Beli. Apabila $\mathrm{F}$ hitung $>\mathrm{F}$ tabel maka hipotesis diterima dan sebaliknya.

Perhitungan koefisien determinasi digunakan untuk mengetahui persentase pengaruh variabel bebas secara bersama-sama terhadap variabel terikat. Jika nilai R2 mendekati 1 maka dapat dikatakan bahwa variabel dependen tersebut dapat variabel independen yang terdapat pada model persamaan tersebut, dan sebaliknya. Kerangka berfikir dalam penelitian ini dapat digambarkan sebagai berikut :

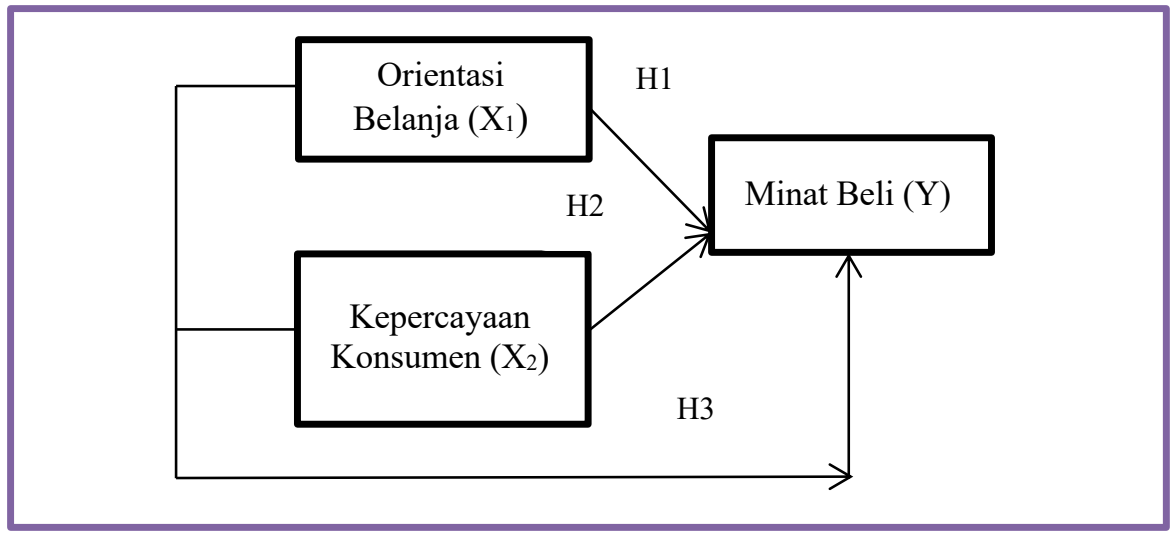

Gambar 1. Kerangka berfikir

Hipotesis dalam penelitian ini adalah:

1. Orientasi Belanja berpengaruh positif dan signifikan terhadap minat beli (H1).

2. Kepercayaan Konsumen berpengaruh positif dan signifikan terhadap minat beli (H2).

3. Orientasi Belanja dan Kepercayaan Konsumen berpengaruh positif dan signifikan terhadap minat beli (H3).

\section{HASIL DAN DISKUSI}

\subsection{Deskripsi Variabel Penelitian}

Deskripsi variabel penelitian dibuat untuk melihat kondisi tanggapan responden terhadap jawaban angket yang sudah disebar. Terdapat 205 responden dengan 25 item pertanyaan. Masingmasing pertanyaan memiliki lima alternatif jawaban yaitu Sangat Setuju (5), Setuju (4), Netral (3), Tidak Setuju (2), dan Sangat Tidak Setuju (1). Jawaban responden ditabulasikan dan dihitung rerata- 
nya. Penghitungan rerata dilakukan untuk mengetahui kategori/nilai dari masing-masing item soal/indikator. Sebelum menghitung rerata setiap item pertanyaan, akan dibuat kategori penilaian terlebih dahulu. Penghitungan rerata dilakukan setelah membuat interval kategori penilaian. Interval kategori penilaian dapat dihitung dengan cara berikut :

$$
\begin{gathered}
\text { Interval }=\frac{\text { nilai tertinggi }- \text { nilai terendah }}{\text { nilai tertinggi }} \\
\text { Interval }=\frac{5-1}{5}=0,8
\end{gathered}
$$

Dengan demikian, interval untuk kategori penilaian adalah sebesar 0,8 , sehingga nilai atau skala yang digunakan dapat dilihat pada tabel berikut :

Tabel 1.

Kategori Penilaian

\begin{tabular}{|c|c|}
\hline Interval & Kategori \\
\hline $5,0-4,3$ & Sangat Baik \\
\hline $4,2-3,5$ & Baik \\
\hline $3,4-2,7$ & Sedang \\
\hline $2,6-1,9$ & Tidak Baik \\
\hline $1,8-1,0$ & Sangat Tidak Baik \\
\hline
\end{tabular}

\subsubsection{Orientasi Belanja $\left(X_{1}\right)$}

Dari 25 pertanyaan kuisioner, terdapat 12 butir pertanyaan untuk variabel Orientasi Belanja (X1) yang terdiri dari 6 indikator yaitu : Shopping Orientation, Brand Consciousness, Price Consciousness, Shopping Confidence, Convinience / Time Consciouness dan Brand / Store Loyalty. Hasil jawaban responden terhadap variabel Orientasi Belajar dapat dilihat pada tabel 2 dibawah ini :

Tabel 2.

\begin{tabular}{|c|c|c|c|c|c|}
\hline \\
\hline No. & Indikator & No. Item & $\mathbf{F}$ & Rerata & Kategori \\
\hline 1. & Shopping Orientation & $1-2$ & 205 & 3,451 & Baik \\
\hline 2. & Brand Consciousness & $3-4$ & 205 & 2,922 & Sedang \\
\hline 3. & Price Consciousness & $5-6$ & 205 & 3,973 & Baik \\
\hline 4. & Shopping Confidence & $7-8$ & 205 & 3,478 & Baik \\
\hline 5. & Convinience Consciousness & $9-10$ & 205 & 3,966 & Baik \\
\hline 6. & Brand/Store Loyalty & $11-12$ & 205 & 3,668 & Baik \\
\hline & Rata-rata variabel & 12 & 205 & 3,576 & Baik \\
\hline
\end{tabular}

Hasil Tanggapan Responden Terhadap Orientasi Belanja $\left(\mathbf{X}_{1}\right)$

(Sumber : Hasil olahan angket penelitian variabel Orientasi Belanja $\mathrm{X}_{1}$ ).

Berdasarkan tabel diatas dapat dilihat bahwa tanggapan responden terhadap Orientasi Belanja berada dalam kategori Baik, yaitu dengan rata-rata 3,58. Dari ke-enam indikator, indikator Price Consciousness berada dalam skor rata-rata yang paling tinggi. Hal tersebut menunjukkan bahwa orientasi berbelanja responden dalam penelitian ini dominan dipengaruhi oleh faktor harga. Konsumen akan selalu mempertimbangkan harga sebelum melakukan pembelian dan mengunjungi berbagai toko online terlebih dahulu untuk membandingkan harga sebelum memutuskan pembelian. Setelah itu faktor dominan yang mempengaruhi orientasi berbelanja responden dalam penelitian ini adalah Convinience Consciousness atau kenyamanan berbelanja. Hal tersebut menunjukkan bahwa responden dalam penelitian ini menyukai berbelanja pada brand atau toko yang sudah disukai. Jika konsumen sudah nyaman dan percaya terhadap suatu brand dan toko, maka konsumen akan cenderung untuk melakukan pembelian yang sama pada toko atau brand tersebut.

\subsubsection{Kepercayaan Konsumen $\left(X_{2}\right)$}


Pada kuisioner penelitian ini, terdapat 6 butir soal untuk variabel Kepercayaan Konsumen $\left(\mathrm{X}_{2}\right)$ yang terdiri dari 3 indikator yaitu Security, Privacy, dan Reliability. Hasil jawaban responden terhadap variabel kepercayaan $\left(\mathrm{X}_{2}\right)$ dapat dilihat pada tabel 3 di bawah ini :

Tabel 3.

Hasil Tanggapan Responden Terhadap Kepercayaan $\left(\mathbf{X}_{2}\right)$

\begin{tabular}{|c|c|c|c|c|c|}
\hline No. & Indikator & No. Item & F & Rerata & Kategori \\
\hline 1. & Security & $13-14$ & 205 & 3,682 & Baik \\
\hline 2. & Privacy & $15-16$ & 205 & 3,773 & Baik \\
\hline 3. & Reliability & $17-18$ & 205 & 3,682 & Baik \\
\hline \multicolumn{2}{|r|}{ Rata-rata variabel } & 6 & 205 & 3,713 & Baik \\
\hline
\end{tabular}

(Sumber : Hasil olahan angket penelitian variabel Kepercayaan $\mathrm{X}_{2}$ ).

Berdasarkan tabel di atas dapat dilihat bahwa secara keseluruhan, tanggapan responden terhadap variabel kepercayaan adalah baik. Skor rerata paling tinggi adalah pada indikator Privacy (keamanan). Hal tersebut menunjukkan bahwa dalam berbelanja online, kerahasiaan data menjadi hal yang sangat penting bagi konsumen. Konsumen tentu saja tidak mau berbelanja pada situs online yang tidak bisa menjaga informasi pelanggan. Selain itu, indikator Security dan Realibiliy memiliki skor rerata yang sama yaitu 3,682. Hal tersebut menunjukkan bahwa keamanan berbelanja dan keandalan situs online menjadi faktor yang sama-sama penting bagi konsumen. Konsumen akan lebih tertarik untuk berbelanja pada toko online yang bisa menjamin keamanan transaksi dan tidak merugikan konsumen. Selain itu faktor keandalan juga penting bagi konsumen. Hal itu berarti konsumen menyukai toko online yang menawarkan produk yang sesuai dengan kebutuhan konsumen.

\subsubsection{Minat beli (Y)}

Pada kuisioner penelitian ini, terdapat 7 butir soal untuk variabel Minat Beli (Y). Indikator minat beli pada penelitian ini adalah Ketertarikan, Keinginan, dan Keyakinan. Hasil jawaban responden terhadap variabel minat beli dapat dilihat pada tabel 4 dibawah ini :

Tabel 4.

Hasil Tanggapan Responden Terhadap Minat Beli (Y)

\begin{tabular}{|c|c|c|c|c|c|}
\hline No. & Indikator & No. Item & F & Rerata & Kategori \\
\hline 1. & Ketertarikan & $19-20$ & 205 & 3,475 & Baik \\
\hline 2. & Keinginan & $21-22$ & 205 & 3,748 & Baik \\
\hline 3. & Keyakinan & $23-25$ & 205 & 3,499 & Baik \\
\hline \multicolumn{2}{|r|}{ Rata-rata variabel } & 7 & 205 & 3,574 & Baik \\
\hline
\end{tabular}

(Sumber : Hasil olahan angket penelitian variabel Orientasi Belanja $\mathrm{X}_{1}$ ).

Berdasarkan hasil tersebut dapat diketahui bahwa variabel minat beli (Y) berada pada kategori Baik. Indikator Keinginan berada dalam skor rerata paling tinggi, hal tersebut menandakan bahwa faktor keinginan menjadi hal yang utama bagi konsumen jika ingin melakukan pembelian secara online. Selain itu faktor yang mendorong minat beli konsumen adalah keyakinan dan ketertarikan.

\subsection{Analisis Regresi Berganda}

Analisis regresi berganda dilakukan untuk mengetahui pengaruh variabel bebas (Orientasi Belanja dan Kepercayaan) terhadap Minat Beli. Pengujian ini juga dilakukan untuk Analisis regresi berganda dilakukan dengan menggunakan aplikasi SPSS. Hasil pengujian analisis regresi berganda dapat dilihat pada tabel 5 di bawah ini : 
Tabel 5.

Koefisien Regresi Pengaruh Orientasi Belanja $\left(X_{1}\right)$ dan Kepercayaan $\left(\mathbf{X}_{2}\right)$ terhadap Minat Belanja $\left(\mathbf{Y}_{1}\right)$

\begin{tabular}{|c|c|c|c|c|c|c|}
\hline \multicolumn{2}{|c|}{ Model } & $\begin{array}{c}\text { Unstandardized } \\
\text { Coefficients }\end{array}$ & & $\begin{array}{c}\text { Standardized } \\
\text { Coefficients }\end{array}$ & & \\
\cline { 3 - 8 } & B & $\begin{array}{c}\text { Std. } \\
\text { Error }\end{array}$ & Beta & T & Sig. \\
\hline 1 & Constant & $-1,340$ & 1,539 & & $-0,871$ &, 385 \\
\hline & $\begin{array}{c}\text { Orientasi Belanja } \\
\text { (X1) }\end{array}$ & 0,274 & 0,46 & 0,342 & 5,971 &, 000 \\
\hline & Kepercayaan (X2) & 0,643 & 0,70 & 0,524 & 9,160 &, 000 \\
\hline
\end{tabular}

a. Dependent Variable : Minat beli $\left(\mathrm{Y}_{1}\right)$

Sumber : Output SPSS, 2021

Berdasarkan tabel diatas, maka persamaan regresi adalah sebagai berikut :

$$
\text { Minat Beli }(Y)=-1,340+0,274 \mathrm{X}_{1}+0,643 \mathrm{X}_{2}+\mathrm{e}
$$

Persamaan regresi di atas mempunyai makna sebagai berikut :

1. Konstanta sebesar 1,340 bernilai negatif menyatakan bahwa jika variabel bebas yaitu Orientasi Belanja dan Kepercayaan dianggap konstan maka minat beli bernilai -1,340. Hal tersebut mengindikasikan bahwa faktor orientasi belanja dan kepercayaan mempengaruhi minat beli konsumen.

2. Koefisien $X_{1}$ sebesar 0,274 bernilai positif menyatakan bahwa orientasi belanja berpengaruh positif terhadap minat beli. Hal tersebut juga mengindikasikan bahwa jika variabel $\mathrm{X}_{1}$ naik $1 \%$ dan variabel $\mathrm{X}_{2}$ dianggap konstan, maka minat beli akan meningkat sebesar 0,274.

3. Koefisien $\mathrm{X}_{2}$ sebesar 0,643 bernilai positif menyatakan bahwa kepercayaan berpengaruh terhadap minat beli. Hal tersebut juga mengindikasikan bahwa jika variabel $\mathrm{X}_{2}$ (kepercayaan) naik 1\%, maka minat beli (Y) akan naik sebesar 0,643 dengan asumsi variabel $\mathrm{X}_{1}$ (orientasi belanja) dianggap konstan.

Sehingga berdasarkan hasil uji regresi berganda tersebut dapat disimpulkan bahwa Orientasi Belanja $\left(\mathrm{X}_{1}\right)$ dan Kepercayaan $\left(\mathrm{X}_{2}\right)$ masing-masing berpengaruh positif terhadap minat beli.

\subsubsection{Pengujian Hipotesis}

\subsubsection{Uji Hipotesis Parsial (Uji T)}

Pengujian hipotesis secara parsial bertujuan untuk melihat pengaruh variabel bebas terhadap variabel terikat secara satu persatu yaitu Orientasi Belanja dan Kepercayaan Konsumen terhadap Minat Beli. Selain itu, uji T dilakukan untuk melihat signifikansi pengaruh variabel bebas terhadap variabel terikat. Berdasarkan hasil uji regresi berganda pada tabel 5, dapat disimpulkan bahwa:

1. Koefisien $X_{1}$ (Orientasi Belanja) sebesar 0,274 bernilai positif menyatakan bahwa terdapat pengaruh positif Orientasi Belanja terhadap Minat Beli. Nilai signifikansi senilai $0,00<0,05$ mengindikasikan bahwa terdapat pengaruh yang signifikan antara Orientasi Belanja dengan Minat Beli sehingga dapat disimpulkan bahwa terdapat pengaruh yang positif dan signifikan antara Orientasi Belanja dengan Minat Beli. Dengan demikian hipotesis 1 (H1) diterima.

2. Koefiesien $\mathrm{X}_{2}$ (Kepercayaan Konsumen) sebesar 0,643 bernilai positif menyatakan bahwa terdapat pengaruh positif antara kepercayaan konsumen dengan Minat Beli. Nilai signifikansi senilai $0,00<0,05$ mengindikasikan bahwa terdapat pengaruh yang signifikan antara Kepercayaan Konsumen dengan Minat Beli sehingga dapat disimpulkan bahwa terdapat pengaruh positif dan signifikan antara Kepercayaan Konsumen dengan Minat Beli. Dengan demikian hipotesis 2 (H2) diterima.

\subsubsection{Uji Hipotesis Simultan (Uji F)}

Uji hipotesis $\mathrm{F}$ dilakukan untuk memihat pengaruh kedua variabel secara bersama-sama terhadap variabel terikat. Hasil pengujian statistik uji $\mathrm{F}$ dengan menggunakan pogram SPSS dapat dilihat pada tabel di bawah berikut ini : 
Tabel 6.

Hasil Perhitungan Uji Hipotesis Secara Simultan (Uji F)

ANOVA ${ }^{\mathrm{a}}$

\begin{tabular}{|c|c|c|c|c|c|c|}
\hline \multicolumn{7}{|c|}{ Coefficients } \\
\hline \multicolumn{2}{|c|}{ Model } & $\begin{array}{c}\text { Sum of } \\
\text { Squares }\end{array}$ & df & $\begin{array}{c}\text { Mean } \\
\text { Square }\end{array}$ & F & Sig \\
\hline \multirow{2}{*}{1} & Regression & 3548,224 & 2 & 1774,112 & 170, &, 00 \\
& $\begin{array}{c}\text { Residual } \\
\text { Total }\end{array}$ & 2104,186 & 202 & 10,417 & 313 & $0^{\mathrm{b}}$ \\
\hline
\end{tabular}

a. Dependent Variable : Minat beli $\left(\mathrm{Y}_{1}\right)$

b. Predictors : (Constant), Total_X $\mathrm{X}_{2}$, Total_X

Sumber : Output SPSS 22, 2021

Berdasarkan tabel di atas diperoleh bahwa nilai $\mathrm{F}$ hitung $=170,31$. Nilai $\mathrm{F}$ tabel adalah sebesar 3, 06 pada taraf $\alpha=0,05$. Dengan demikian $F$ hitung $>\mathrm{F}$ tabel yaitu 170,313 $>3,06$ serta nilai signifikansi sebesar $0,00<0,05$, maka H3 dapat diterima sehingga dapat disimpulkan bahwa Orientasi Belanja dan Kepercayaan Konsumen memiliki pengaruh secara simultan (bersama-sama) dan signifikan terhadap Minat Beli Konsumen pada toko online Shopee.

\subsubsection{Koefisien Determinasi $\left(\mathrm{R}^{2}\right)$}

Koefisien determinasi adalah alat untuk melihat seberapa jauh kemampuan model dalam menerangkan variasi variabel dependen. Nilai koefisien determinasi (R2) yang kecil memiliki arti bahwa kemampuan variabel bebas dalam menjelaskan variabel dependen sangat terbatas. Sebaliknya jika nilai koefisien determinasi $\left(\mathrm{R}^{2}\right)$ mendekati 1 , berarti variabel-variabel independen mampu menjelaskan dan memberikan semua informasi yang dibutuhkan untuk memprediksi variasi variabel independen. Hasil uji koefisien determinasi dapat dilihat pada tabel 7 dibawah ini :

Tabel 7.

Hasil Koefisien Determinasi $\left(\mathbf{R}^{2}\right)$

Model Summary ${ }^{\mathrm{b}}$

\begin{tabular}{|c|c|c|c|c|}
\hline \multicolumn{5}{|c|}{ Coefficients } \\
\hline Model & $\mathbf{R}$ & $\begin{array}{c}\mathbf{R} \\
\text { Square }\end{array}$ & $\begin{array}{c}\text { Adjusted } \\
\text { R Square }\end{array}$ & $\begin{array}{c}\text { Std. Error } \\
\text { of the } \\
\text { Estimate }\end{array}$ \\
\hline 1 &, $792^{\mathrm{a}}$ &, 628 &, 624 & 3,228 \\
\hline
\end{tabular}

a. Predictors : (Constant), Orientasi Belanja, Kepercayaan Konsumen

b. Dependent Variable : Minat Beli

Sumber : Output SPSS, 2021

Berdasarkan tabel di atas dapat diketahui bahwa nilai Adjusted $R$ Square adalah 0,624 atau $62,4 \%$. Hal ini menunjukkan bahwa persentase sumbangan pengaruh Orientasi Belanja dan Kepercayaan Konsumen terhadap Minat Beli adalah sebesar 62,4\%. Sedangkan sisanya dipengaruhi oleh variabel lain yang tidak dimasukkan dalam model penelitian ini.

\subsection{Pembahasan}

\subsubsection{Pengaruh Orientasi Belanja Terhadap Minat Beli}

Hasil penelitian menunjukkan bahwa koefisien variabel Orientasi Belanja $\left(\mathrm{X}_{1}\right)$ adalah sebesar 0,274 dengan nilai signifikansi 0,000 sehingga dapat disimpulkan bahwa orientasi belanja berpengaruh positif dan signifikan terhadap minat beli secara online. Hasil penelitian ini relevan dengan penelitian yang dilakukan oleh (Nurhidayah, 2020) dimana hasil penelitiannya adalah terdapat pengaruh positif dan signifikan terhadap minat beli konsumen secara online. Hasil penelitian tersebut juga menunjukkan bahwa gaya fashion mahasiswa dipengaruhi oleh faktor internal dan eksternal dan yang paling dominan adalah faktor eksternal yaitu pengaruh teman 
sebaya. Jika temannya menggunakan suatu barang yang terlihat bagus, maka ada keinginan untuk membeli barang yang sama dan di toko yang sama, dan hal tersebut mempengaruhi minat beli konsumen.

Hasil penelitian ini juga relevan dengan penelitian yang dilakukan oleh (Ivoni et al., 2015) yang berjudul Pengaruh Persepsi Harga, Orientasi Merek, dan Orientasi Belanja Terhadap Minat Beli Fashion Online. Penelitian tersebut menemukan bahwa terdapat pengaruh positif dan siginifikan orientasi belanja terhadap minat beli konsumen secara online.

Penelitian lainnya yang relevan dengan penelitian ini adalah penelitian yang dilakukan oleh (Ikranegara, 2017) dengan topik Pengaruh Orientasi Belanja, Kepercayaan Online, dan Pengalaman Pembelian Terhadap Minat Beli Secara Online (Studi Kasus Pada Toko Online Bukalapak) . Hasil penelitian tersebut menyatakan bahwa terdapat pengaruh positif dan signifikan orientasi belanja terhadap minat beli konsumen secara online.

\subsubsection{Pengaruh Kepercayaan Konsumen Terhadap Minat Beli}

Hasil penelitian ini sejalan dengan penelitian yang dilakukan oleh (Sullivan \& Kim, 2018) bahwa kepercayaan konsumen sangatlah penting dalam mempengaruhi minat beli konsumen. Disamping itu, faktor-faktor evaluasi produk juga penting dalam menentukan minat beli konsumen, khususnya untuk melakukan pembelian ulang. Kepercayaan online adalah penentu utama minat beli konsumen. Oleh karena itu, toko online sangat perlu menjaga kepercayaan konsumen dengan cara memberikan pelayanan yang sebaik-baiknya, memberikan foto atau gambar produk yang sesuai dengan aslinya, mengirimkan barang kepada konsumen sesuai dengan waktu yang sudah dijanjikan, dan tidak menjual barang tiruan atau palsu dengan menyatakan bahwa itu adalah brand asli kepada kosumen.

(Zuharroh, 2020) dalam penelitiannya yang berjudul Pengaruh Orientasi Belanja, Kepercayaan, dan Pengalaman Pembelian, Terhadap Minat Beli Secara Online menyimpulkan bahwa kepercayaan konsumen berpengaruh positif dan siginifikan terhadap minat beli. Minat beli konsumen secara berulang akan terjadi jika kepuasan didapatkan konsumen mampu membangun kepercayaan konsumen bahwa online shop tempat mereka berbelanja dapat dipercaya dan diandalkan untuk memenuhi kebutuhan dan keinginan mereka serta menunjukan niat untuk memberikan pelayanan yang terbaik bagi konsumen.

\subsubsection{Pengaruh Orientasi Belanja dan Kepercayaan Konsumen Terhadap Minat Beli}

Hasil uji simultan dalam penelitian ini menunjukkan bahwa nilai F-hitung sebesar 170,313 > F tabel sebesar 3,06, maka dapat disimpulkan bahwa Orientasi Belanja dan Kepercayaan Konsumen secara bersama-sama berpengaruh terhadap Minat Beli. Nilai signifikansi yang diperoleh sebesar $0,000(0,000<0,05)$ maka hal ini menunjukkan Orientasi Belanja dan Kepercayaan Konsumen secara simultan berpengaruh positif dan signifikan terhadap Minat Beli, sehingga hipotesis ketiga terbukti yang menyatakan bahwa Orientasi Belanja dan Kepercayaan Konsumen berpengaruh positif dan signifikan terhadap Minat Beli Konsumen.

\section{KESIMPULAN}

Berdasarkan hasil pembahasan dan pengujian statistik dalam penelitian, maka dapat disimpulkan terdapat pengaruh yang positif dan signifikan Orientasi Belanja dan Minat Beli konsumen. Semakin tinggi orientasi belanja konsumen maka minat pembelian online akan meningkat. Dengan demikian, toko online Shopee sebaiknya memanfaatkan kondisi kecenderungan impulsif berbelanja dari konsumen dengan cara memberikan pelayanan terbaik, menawarkan berbagai promo yang menarik atau diskon agar konsumen mau melakukan pembelian dan pembelian berulang.

Berdasarkan hasil penelitian ini juga dapat disimpulkan terdapat pengaruh yang positif dan signifikan Kepercayaan Konsumen terhadap Minat Beli. Kepercayaan konsumen akan mendorong konsumen untuk berbelanja di online shop yang sama yang telah memberikan mereka pelayanan yang baik. Oleh karena itu, online shop Shopee diharapkan menggunakan strategi yang tepat untuk mempertahankan kepercayaan pelanggan. Para penjual pada online shop Shopee harus memberikan 
informasi produk secara detail baik mengenai harga produk, spesifikasi produk dengan jujur, dan juga mengenai informasi pembayaran.

Untuk dapat bertahan dan bahkan memenangkan persaingan dalam pasar berbasis online saat ini, setiap pedangan pada toko online Shopee harus memahami faktor orientasi belanja pelanggan dan menjaga kepercayaan konsumen untuk mendorong dan memperkuat minat beli konsumen di toko mereka. Pemilik online shop Shopee harus terus menjual barang-barang dengan kualitas yang terjamin dan disukai oleh para pelanggan. Dengan begitu, eksistensi online shop Shopee akan terus bertahan dan bahkan dapat memenangkan persaingan ditengah menjamurnya online shop saat ini.

Penelitian ini masih memiliki keterbatasan baik dari segi jumlah variabel dan objek penelitian, sehingga untuk penelitian berikutnya disarankan menambah variabel penelitian, dan juga menambah objek penelitian, sehingga hasil penelitian dapat digeneralisasikan.

\section{REFERENSI}

Afnina, A., \& Hastuti, Y. (2018). Pengaruh Kualitas Produk Terhadap Kepuasan Pelanggan. Jurnal Samudra Ekonomi Dan Bisnis, 9(1), 21-30.

Anwar, R., \& Adidarma, W. (2016). Pengaruh Kepercayaan dan Risiko Pada Minat Beli Belanja Online. Jurnal Manajemen Dan Bisnis Sriwijaya, 14(2), 155-168. https://doi.org/10.29259/jmbs.v14i2.3995

Bibi, S., \& Jati, H. (2015). Efektivitas Model Blended Learning Terhadap Motivasi dan Tingkat Pemahaman Mahasiswa Mata Kuliah Algoritma dan Pemrograman. Jurnal Pendidikan Vokasi, $5(1), 74-87$.

Firdayanti, R. (2013). Persepsi Resiko Melakukan E-Commerce Dengan Kepercayaan Konsumen Dalam Membeli Produk Fashion Online. 1(1), 1-7.

Gita Ardy Putri, G. (2020). Analisis Trust Website Quality dan Orientasi Belanja terhadap minat beli online shop pada mahasiswa fakultas Ekonomi dan Bisnis Ups Tegal. Universitas Pancasakti Tegal.

Haekal, A., \& Widjajanta, B. (2016). Pengaruh Kepercayaan dan Persepsi Risiko Terhadap Minat Membeli Secara Online Pada Pengunjung Website Classifieds di Indonesia. Journal of Business Management Education (JBME), 1(1), 183-195.

Ikranegara, D. P. (2017). Pengaruh Orientasi Belanja, Kepercayaan Online, dan Pengalaman Pembelian Terhadap Minat Beli Secara Online. Skripsi, 6, 5-9.

Imari, S., Lubis, P. H., \& Chan, S. (2017). Pengaruh Orientasi Belanja, Kepercayaan Online Dan Pengalaman Pembelian Sebelumnya Terhadap Niat Pembelian Konsumen Secara Online Dengan Perbedaan Gender Sebagai Variabel Pemoderasi. Jurnal Perspektif Manajemen Dan Perbankan, $8(3), 49-70$.

Ivoni, D., Santika, I. W., \& Suryani, A. (2015). Pengaruh Persepsi Harga, Orientasi Merek, dan Orientasi Belanja Terhadap Niat Beli Fashion Online. E-Jurnal Manajemen, 4(4).

Khotimah, K., \& Febriansyah, F. (2018). Pengaruh Kemudahan Penggunaan, Kepercayaan Konsumen dan Kreativitas Iklan Terhadap Minat Beli Konsumen Online-Shop. Jurnal Manajemen Strategi Dan Aplikasi Bisnis, 1(1), 19-26.

Kusuma, D. F., \& Septarini, B. G. (2013). Pengaruh Orientasi Belanja Terhadap Intensi Pembelian Produk Pakaian Secara Online Pada Pengguna Online Shop. Jurnal Psikologi Industri Dan Organisasi, 2(3). 
Lapian, S. J., \& Roring, F. (2018). Pengaruh Kepercayaan, dan Motivasi terhadap Minat Beli Pengguna Shoppe secara Online Pada Anggota Pemuda GMIM Zaitun Mahakeret. Jurnal EMBA: Jurnal Riset Ekonomi, Manajemen, Bisnis Dan Akuntansi, 6(4).

Malhotra, N. K. (2009). Riset Pemasaran: Pendekatan Terapan Jilid 1 Edisi 4. Jakarta: Indeks.

Nurhidayah, L. (2020). Pengaruh Orientasi Dan Kepercayaan Belanja Terhadap Minat Beli Secara Online Pada Toko "Shopee."

Nurrahmanto, P. A. (2015). Pengaruh Kemudahan Penggunaan, Kenikmatan Berbelanja, Pengalaman Berbelanja, dan Kepercayaan Konsumen Terhadap Minat Beli Konsumen Di Situs Jual Beli Online Bukalapak.com. Feb Undip, 20.

Nusarika, L. A. K., \& Purnami, N. M. (2015). Pengaruh Persepsi Harga, Kepercayaan, dan Orientasi Belanja Terhadap Niat Beli Secara Online ( Studi pada Produk Fashion Online di Kota Denpasar ). 4(8), 2380-2406.

Sreya, R., \& Raveendran, P. T. (2016). Effect of Shopping Orientation on Attitude Towards Online Shopping-A Multiple Regression Approach. Management Insight, 12(2), 51-57.

Sugiyono, M. (2012). Metode Penelitian Kuantitatif R\&D. Alfabeta.

Suhari, Y. (2011). Kepercayaan Terhadap Internet Serta Pengaruhnya Pada Pencarian Informasi Dan Keingingan Membeli Secara Online. Jurnal Dinamika Informatika, 3(1).

Sullivan, Y. W., \& Kim, D. J. (2018). Assessing the Effects of Consumers' Product Evaluations and Trust on Repurchase Intention in E-Commerce Environments. International Journal of Information Management, 39, 199-219.

Wijayanti, R. F., Pribadi, J. D., \& Budiarti, L. (2018). Pengaruh Orientasi Belanja Konsumen Terhadap Minat Pembelian Secara Online. Jurnal Administrasi Dan Bisnis, 12, 162-168.

Zuharroh, A. G. N. (2020). Pengaruh Orientasi Belanja, Kepercayaan dan Pengalaman Pembelian terhadap Minat Beli Secara Online (Studi pada Toko Online Shopee). STIE YKPN.

Website

https://wearesocial.com/digital-2020

https://www.goodnewsfromindonesia.id/2020/08/26/menelisik-tren-peningkatan-pengguna-internetdi-indonesia 